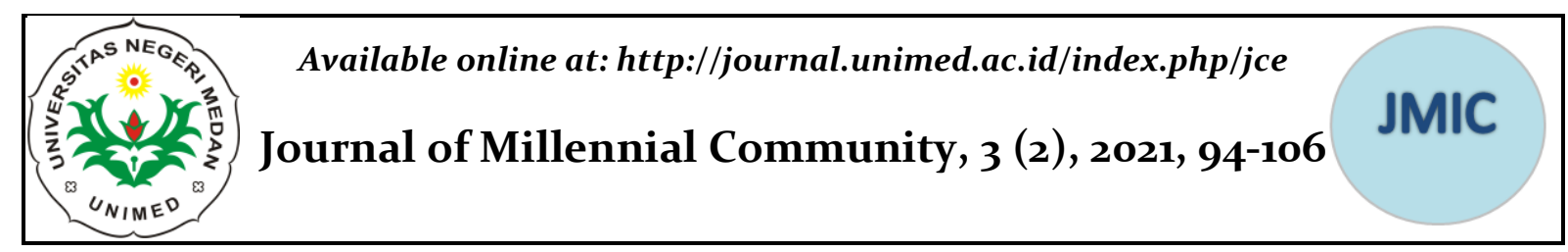

\title{
Life Skill Sebagai Langkah Pemberdayaan Masyarakat Menuju Kemandirian Ekonomi
}

\author{
Ragil Atmaja ${ }^{1}$, Nurlaila² ${ }^{2}$ Rahman Arif ${ }^{3}$, Rahmi Atikah \\ ${ }^{12}$ Sekolah Menengah Kejuruan Pekerja Sosial (SMK 9), Sumatera Utara \\ 34 Program Studi Pendidikan Masyarakat, Universitas Negeri Medan \\ Email : ragilatmaja19@gmail.com
}

\begin{abstract}
$\underline{\text { Abstrak }}$
Pendidikan keterampilan (life skill) dalam rangka pemberdayaan kepada masyarakat guna mempersiapkan individu yang mandiri sehingga mampu terberdayakan untuk kehidupan mereka. Pemberdayaan masyarakat sebagai proses pengembangan, memandirikan, dan memperkuat elemen masyarakat yang memiliki kondisi sosial ekonomi yang rendah. Kegiatan pemberdayaan melalui pendidikan keterampilan berhasil membawa diri individu menjadi terampil secara pengetahuan, perilaku, dan mengorganisasikan diri dan lingkungan sosial. Pemberdayaan masyarakat sebagai proses pengembangan, memandirikan, dan memperkuat elemen masyarakat yang memiliki kondisi sosial ekonomi yang rendah. Kegiatan pemberdayaan melalui pendidikan keterampilan berhasil membawa diri individu menjadi terampil secara pengetahuan, perilaku, dan mengorganisasikan diri dan lingkungan sosial
\end{abstract}

Kata Kunci : Life Skiil, Pemberdayaan Masyarakat, Ekonomi

\section{Life Skills as a Step Towards Empowering The Community Towards Economic Independence}

\begin{abstract}
Skills education (life skill) in the context of community empowerment to prepare independent individuals so that they are empowered for their lives. Community empowerment is a process of developing, empowering, and strengthening elements of society that have low socioeconomic conditions. Empowerment activities through skills education succed in bringing individuals to become skilled in knowledge, behaviour, and organizing themselves and the social environment. Community empowerment is a process of developing, empowering, and strengthening elements of society that have low socioeconomic conditions. Empowerment activities through skills education succed in bringing individuals to become skilled in knowledge, behaviour, and organizing themselves and the social environment.
\end{abstract}

Keywords: Skill Education, Life skill, Empowerment, Economics.

\section{PENDAHULUAN}

Bangsa Indonesia telah memasuki era globalisasi dan demokrasi yang maju serta desentralisasi yang luas dengan pelaksanaan otonomi daerah yang bertujuan untuk meningkatkan

pelayanan guna tercapainya

kesejahteraan masyarakat. Namun demikian kita masih menghadapi berbagai permasalahan pada berbagai aspek. Masalah moral, ekonomi 


\section{Journal of Millennial Community, 3 (2), September 2021 \\ Ragil Atmaja, Nurlaila, Rahman Arif, Rahmi Atikah}

kerakyatan, pendidikan, kesehatan, kekerasan dalam rumah tangga, perdagangan perempuan dan anak dan sebagainya yang semuanya memerlukan prioritas untuk penanganan dan penanggulangannya.

Kegiatan membangun masyarakat terkait erat dengan memberdayakan masyarakat karena di samping memerangi kemiskinan dan kesenjangan, juga mendorong masyarakat menjadi lebih aktif dan penuh inisiatif. Pemberdayaan masyarakat sendiri merupakan upaya untuk memandirikan masyarakat, lewat perwujudan potensi kemampuan yang dimiliki. Pengembangan potensi manusia salah satunya dapat diwujudkan melalui kegiatan pendidikan berbasis kemasyarakatan dengan menekankan pentingnya memahami kebutuhan masyarakat dan cara pemecahan permasalahan oleh masyarakat dengan memperhatikan potensi yang ada di lingkungannya.

Kebutuhan masyarakat akan pendidikan sangat tinggi khususnya pendidikan nonformal (PNF) terus mengalami peningkatan agar mereka semakin berdaya. Banyak faktor yang mendorong terjadinya peningkatan kebutuhan PNF dalam kehidupan masyarakat. Perubahan masyarakat yang sangat cepat menyebabkan hasil pendidikan yang diperoleh di sekolah (pendidikan formal) menjadi tidak sesuai lagi atau tertinggal dari tuntutan baru dalam dunia kerja. Ilmu

pengetahuan dan atau ketrampilan yang didapatkan dari sekolah cepat menjadi usang dan kurang dapat digunakan untuk memecahkan masalah-masalah baru dalam kehidupan seharihari. Hal ini sejalan dengan apa yang telah disampaikan Muhaimin Iskandar,
Menteri Tenaga Kerja dan Transmigarasi mengatakan, kesempatan kerja yang ada tidak dapat diisi oleh pencari kerja atau lulusan sekolah. Kondisi ini dapat terjadi karena ketidaksesuaian kompetensi atau bahkan tidak memiliki kompetensi sama Page|95 sekali, padahal pasar kerja membutuhkan angkatan kerja atau lulusan sekolah yang memiliki kompetensi tertentu. Pengangguran lulusan SMA, Diploma (D1, D2, D3), dan $\mathrm{S}_{1}$ meningkat masingmasing $0,19 \%, \quad 2,45 \%$, dan $0,49 \%$. Pengangguran lulusan SMU mencapai 14,5\%, SMK 14,9\%, Diploma 13,66\%, dan Sarjana 13,08\% (Kedaulatan Rakyat, 4 Januari 2009).

Penyelenggaran kurikulum berbasis kompetensi di Lembaga Kursus dan Keterampilan (LKP), merupakan bagian dari proses pendidikan nonformal untuk meningkatkan kualitas dan produktifitas sumber daya manusia. Implementasi kurikulum berbasis kompetensi ini merupakan penjabaran dari amanat UU No. 20 Tahun 2003 tentang Sistem Pendidikan Nasional dan PP No. 19 Tahun 2005 tentang Standar Nasional Pendidikan. Peningkatan mutu penyelenggaraan dan mutu lulusan kursus ada di bawah tanggung jawab sub Direktorat Mutu Kursus, Direktorat Pembinaan Kursus dan Kelembagaan (Dir.Binsuskel). Program-program yang dikembangkan pada Sub Direktorat Mutu Kursus adalah: (1) pengembangan kurikulum kursus berbasis kompetensi; (2) pengembangan bahan ajar/modul kursus; (3) pengembangan norma penjaminan mutu kompetensi lulusan; (4) pengembangan bank soal ujian nasional; (5) pengembangan lembaga sertifikasi profesi (LSK); pengembangan tempat uji kompetensi (TUK); dan (7) peningkatan ka[asitan LSK dan TUK. 


\section{Journal of Millennial Community, 3 (2), September 2021 \\ Ragil Atmaja, Nurlaila, Rahman Arif, Rahmi Atikah}

Berdasarkan pemaparan di atas maka perlu dikembangkan sebuah strategi pemberdayaan masyarakat yang nantinya akan membantu mereka lebih berdaya. Hal ini dikarenakan selama ini belum ditemukan hasil atau perubahan nyata sebagai dampak apakah program ini cukup efektif untuk memberdayakan masyarakat. Keberhasilan program tentu tidak terlepas dari strategi yang diterapkan dalam proses pelaksanaan program. Untuk mengetahui hal ini, diperlukan pengkajian untuk menggambarkan proses tersebut. Dari penggambaran proses pelaksanaan program dapat diketahui apakah program tersebut telah sesuai dengan strategi pemberdayaan masyarakat.

Salah satu karakteristik bangsa yang ideal adalah bangsa yang mandiri. Bangsa mandiri adalah bangsa yang mampu berdiri sendiri tanpa bergantung dengan negara lain. Bangsa yang mandiri tidak meminta, tidak menunggu dan tidak berharap uluran tangan negara lain. Kemandirian perekonomian Indonesia berdasarkan ekonomi Pancasila adalah kemandirian ekonomi nasional berlandaskan nilai-nilai yang diperjuangkan pendiri bangsa sesuai amanah Undang-Undang Dasar (UUD) 1945. Kemandirian ini juga tidak dimaksudkan tak peduli dengan perekonomian global, justru kemandirian ekonomi nasional yang mampu survive guna menyejahterakan rakyat. Saat ini kemandirian ekonomi rakyat Indonesia secara umum, masih belum dapat dikatakan mandiri, bahkan masih jauh dari kemandirian.

Pertumbuhan ekonomi Indonesia menuju kemandirian ekonomi nasional, merupakan sesuatu hal penting yang perlu dilakukan dalam rangka menumbuhkan pemikiran dan semangat nasionalisme ekonomi yang berpijak pada kemandirian bangsa dengan berbagai kegiatan ekonomi yang sangat produktif dan kreatif. Di Indonesia sebenarnya telah memilki suatu sektor yang sangat potensial yakni UMKM. Untuk Page|96 pengembangan sektor ini maka sangat perlu dialakukan berbagai upaya dalam bentuk pelatihan ataupun cara lainnya untuk mengembangkan sektor ini. Salah satu upayanya yakni dengan penanaman wawasan Entrepreneur kepada masyarakat pelaku UMKM. Bahasan dalam paper ini ialah bahwa dengan wawasan Entrepreneur ini maka UMKM akan dapat lebih berperan dalam banyaknya penciptaan lapangan kerja baru, sehingga para angkatan kerja akan terserap. Dengan adanya berbagai inovasi dari UMKM dengan wawasan entrepreneur akan meningkatkan produktivitas yang lebih.

\section{KETERAMPILAN HIDUP (LIFE SKILL)}

Pendidikan adalah semua perbuatan dan usaha dari seorang pendidik untuk mengolah pengetahuannya, pengalamannya, kecakapannya, serta keterampilannya Saliman, Shudarsono (1993, h.178). Program pendidikan sering dikaitkan dengan orang-orang dewasa yang memiliki segudang pengalaman, sehingga diperlukan pendekatan andragogi dan pendekatan partisipatif dalam setiap tahapan kegiatan dari perencanaan sampai penilaian.

Sedangkan keterampilan adalah kemampuan untuk mengerjakan atau melaksanakan sesuatu dengan baik Nasution (1975, h.28). Maksud dari pendapat tersebut bahwa kemampuan adalah kecakapan dan potensi yang dimiliki oleh seseorang untuk menguasai suatu keahlian yang dimilikinya sejak 


\section{Journal of Millennial Community, 3 (2), September 2021 \\ Ragil Atmaja, Nurlaila, Rahman Arif, Rahmi Atikah}

lahir. Kemampuan tersebut merupakan suatu hasil latihan yang digunakan untuk melakukan sesuatu. Melalui pendapat di atas dapat disimpulkan bahwa kemampuan seseorang itu dapat tumbuh melalui latihan-latihan yang dilakukan oleh orang itu sendiri.

Keterampilan (skill) dalam arti sempit yaitu kemudahan, kecepatan, dan ketepatan dalam tingkah laku motorik yang disebut juga normal skill. Sedangkan dalam arti luas, keterampilan meliputi aspek normal skill, intelektual skill, dan sosial skill Vembriarto (1981, h.52). Dari beberapa pendapat di atas dapat disimpulkan bahwa keterampilan adalah kemampuan untuk melakukan sesuatu dengan baik, cepat, dan tepat. Keterampilan akan dapat dicapai atau ditingkatkan dengan latihan tindakan secara berkesinambungan.

Banyak sekali dan bercorak-ragam kebutuhan akan pendidikan untuk usaha pembangunan pedesaan, namun untuk keperluan praktis seluruh kebutuhan itu menurut Philip dan Manzoor (1985, h.2122) dapat dibagi dalam empat kelompok:

1. Pendidikan Umum dan Dasar: melekaksara, melek-angka, pengertian dasar mengenai ilmu pengetahuan dan lingkungan dan sebagainya, yang pada umumnya diusahakan oleh sekolah dasar dan sekolah lanjutan umum.

2. Pendidikan Kesejahteraan Keluarga: terutama dirancangkan untuk menyebarkan pengetahuan, keterampilan dan watak yang bermanfaat untuk meningkatkan kesejahteraan keluarga, mencakup mata pelajaran seperti ilmu kesehatan, ilmu gizi, kepandaian rumah tangga dan mengasuh anak-anak, pemeliharaan dan penyempurnaan perumahan, KB dan sebagainya.

3. Pendidikan Kemasyarakatan: yang bertujuan mengokohkan dan menyempurnakan lembaga-lembaga dan prosesproses daerah dan nasional melalui pengajaran tentang soal-soal pemerintah daerah dan negara, gerakan koperasi, proyek pembangunan masyarakat dan sebagainya.

4. Pendidikan

Kejuruan: dirancangkan untuk membina kepandaian atau keterampilan tertentu, yang berkaitan dengan berbagai kegiatan dalam bidang ekonomi, dan yang berfaedah untuk mencari nafkah.

\section{PEMBERDAYAAN MASYARAKAT}

Konsep Strategi Pemberdayaan Masyarakat Strategi adalah cara untuk mengerahkan tenaga, dana, daya, dan peralatan yang dimiliki guna mencapai tujuan yang ditetapkan. Arti pemberdayaan masyarakat itu sendiri adalah suatu proses yang mengembangkan dan memperkuat kemampuan masyarakat untuk terus terlibat dalam proses pembangunan yang berlangsung secara dinamis sehingga masyarakat dapat menyelesaikan masalah yang dihadapi serta dapat mengambil keputusan secara bebas (independent) dan mandiri (Sumaryo, 1991). Hikmat (2001:12) menjelaskan ada beberapa faktor internal yang menghambat pemberdayaan antara lain, kurang bisa untuk saling mempercayai, kurang daya inovasi atau kreativitas, mudah pasrah atau menyerah atau putus asa, aspirasi dan cita-cita rendah, tidak mampu menunda menikmati hasil kerja, wawasan waktu yang sempit, familisme, sangat tergantung pada bantuan pemerintah, sangat terikat pada tempat kediamannya dan tidak mampu atau tidak bersedia menempatkan diri sebagai orang lain.

Menurut Sutoro Eko (Cholisin, 2011) bahwa pemberdayaan sebagai proses mengembangkan, memandirikan, 


\section{Journal of Millennial Community, 3 (2), September 2021}

Ragil Atmaja, Nurlaila, Rahman Arif, Rahmi Atikah

menswadayakan, memperkuat posisi tawar menawar masyarakat lapisan bawah terhadap kekuatan-kekuatan penekan di segala bidang dan sektor kehidupan. Konsep pemberdayaan (masyarakat desa) dapat dipahami juga dengan dua cara pandang. Pertama, pemberdayaan dimaknai dalam konteks menempatkan posisi berdiri masyarakat. Posisi masyarakat bukanlah obyek penerima manfaat (beneficiaries) yang tergantung pada pemberian dari pihak luar seperti pemerintah, melainkan dalam posisi sebagai subyek (agen atau partisipan yang bertindak) yang berbuat secara mandiri. Berbuat secara mandiri bukan berarti lepas dari tanggungjawab negara. Pemberian layanan publik (kesehatan, pendidikan, perumahan, transportasi dan seterusnya) kepada masyarakat tentu merupakan tugas (kewajiban) negara secara given. Masyarakat yang mandiri sebagai partisipan berarti terbukanya ruang dan kapasitas mengembangkan potensikreasi, mengontrol lingkungan dan sumberdayanya sendiri, menyelesaikan masalah secara mandiri, dan ikut menentukan proses politik di ranah negara. Masyarakat ikut berpartisipasi dalam proses pembangunan dan pemerintahan.

Menurut Sumodiningrat (1996, h.185) menyatakan memberdayakan masyarakat adalah upaya untuk meningkatkan harkat dan martabat lapisan masyarakat yang dalam kondisi sekarang tidak mampu untuk melepaskan diri dari perangkat kemiskinan dan keterbelakangan. Dengan kata lain pemberdayaan bermaksud untuk mengembangkan kemampuan masyarakat agar secara mandiri memiliki keterampilan untuk mengatasi masalah-masalah mereka sendiri.
Pemberdayaan masyarakat, secara lugas dapat diartikan sebagai suatu proses yang membangun manusia atau masyarakat melalui pengembangan kemampuan masyarakat, perubahan perilaku masyarakat, dan pengorganisasian Page|98 masyarakat. Dari definisi tersebut terlihat ada 3 tujuan utama dalam pemberdayaan masyarakat yaitu mengembangkan kemampuan masyarakat, mengubah perilaku masyarakat, dan mengorganisir diri masyarakat. Priyono (Arisah, 2009) memberikan makna pemberdayaan masyarakat sebagai upaya menjadikan suasana kemanusiaan yang adil dan beradab menjadi semakin efektif secara struktural, baik dalam kehidupan keluarga, masyarakat, negara, regional, internasional maupun dalam bidang politik, ekonomi, psikologi dan lain-lain. Memberdayakan masyarakat mengandung makna mengembangkan, memandirikan, menswadayakan dan memperkuat posisi tawar-menawar masyarakat lapisan bawah terhadap kekuatan penekan di segala bidang dan sektor kehidupan

Pemberdayaan masyarakat muncul karena adanya suatu kondisi sosial ekonomi masyarakat yang rendah mengakibatkan mereka tidak mampu dan tidak tahu. Ketidakmampuan dan ketidaktahuan masyarakat mengakibatkan produktivitas mereka rendah. Pemberdayaan masyarakat dilaksanakan melalui : (1) Pengembangan masyarakat, (2) Pengorganisasian masyarakat (Nuryasin, 2011).

Berdasarkan makna katanya, pemberdayaan atau empowerment. diartikan sebagai kekuatan yang berasal dari dalam yang dapat diperkuat dengan unsur-unsur dari luar (Kartasasmita, 1996). 
Sebagai proses, pemberdayaan mempunyai tiga tahapan: penyadaran, pengkapasitasan, dan pendayaan" Wrihatnolo dan Nugroho (2007, h.2).

1. Tahap pertama adalah penyadaran. Pada tahap ini target yang hendak diberdayakan diberikan pencerahan dalam bentuk pemberian penyadaran bahwa mereka mempunyai hak untuk memiliki sesuatu.

2. Tahap kedua adalah pengkapasitasan. atau disebut capacity building atau dalam bahasa yang lebih sederhana yaitu memampukan atau enabling. Pengkapasitasan manusia artinya memampukan manusia baik dalam konteks individu maupun keompok seperti melalui pelatihan, workshop, seminar dan lain sebagainya.

3. Tahap ketiga adalah pemberian daya itu sendiri atau empowerment dalam makna yang lebih sempit. Pada tahap ini target diberikan daya, kekuasaan, otoritas maupun peluang. Pemberian ini sesuai dengan kecakapan dan kualitas yang telah dimiliki.

Schwartz dalam Suharto (2006) mengemukakan lima tugas yang dapat dilaksanakan oleh penyelenggara program pemberdayaan masyarakat sebagai berikut:

1. Mencari persamaan mendasar antara persepsi masyarakat mengenai kebutuhan mereka sendiri dan aspekaspek tuntutan sosial yang dihadapi mereka.

2. Mendeteksi dan menghadapi kesulitan-kesulitan yang menghambat banyak orang dan membuat frustasi usaha-usaha orang untuk mengidentifikasi kepentingan mereka dan kepentingan orang-orang yang berpengaruh terhadap mereka.
3. Memberikan kontribusi data mengenai ide-ide, fakta, nilai, konsep yang tidak dimiliki masyarakat,tetapi bermanfaat bagi mereka dalam menghadapi realitas sosial dan masalah yang dihadapi mereka.

4. Membagi visi kepada masyarakat, harapan, dan aspirasi penyelenggara merupakan investasi bagi interaksi orang, masyarakat, dan kesejahteraan individu serta sosial.

5. Mendefinisikan syarat-syarat dan batasan-batasan situasi dengan sistem relasi antara pihak penyelenggara program dan masyarakat sasaran program yang dibentuk. Aturan-aturan tersebut membentuk konteks bagi 'kontrak kerja' yang mengikat masyarakat dan lembaga. Batasan-batasan tersebut juga mampu menciptakan kondisi yang dapat membuat masyarakat dan pihak penyelenggara program pemberdayaan masyarakat menjalankan fungsinya masing-masing.

Hikmat (2001: 12) menjelaskan ada beberapa faktor internal yang menghambat pemberdayaan antara lain kurang bisa untuk saling mempercayai, kurang daya inovasi/ kreativitas, mudah pasrah/ menyerah/ putus asa, aspirasi dan cita-cita rendah, tidak mampu menunda menikmati hasil kerja, wawasan waktu yang sempit, familisme, sangat tergantung pada bantuan pemerintah, sangat terikat pada tempat kediamannya, dan tidak mampu/ tidak bersedia menempatkan diri sebagai orang lain.

\section{KEMANDIRIAN EKONOMI}

\section{Pengertian Ilmu Ekonomi}

Dalam buku Pengantar Ekonomi teori dan aplikasi menurut Sukirno, Sadono (2018:1-3) Kata ekonomi petama kali digunakan oleh Xenophone, seorang ahli 


\section{Journal of Millennial Community, 3 (2), September 2021}

Ragil Atmaja, Nurlaila, Rahman Arif, Rahmi Atikah

filsafat Yunani. Istilah ekonomi bersal dari suku kata yunani yaitu : OIKOS dan NOMOS yang artinya pengaturan rumah tangga. Dengan demikian, secara sederhana ekonomi dapat diartikan sebagai kaidah-kaidah, aturan-aturan, cara pengelolaan rumah tangga. Sedangkan ilmu yang mempelajari bagaimana tiap rumah tangga atau masyarakat mengelola sumber daya yang mereka miliki untukmemenuhi kebutuhan mereka disebut ilmu ekonomi. Secara lebih luas ilmu ekonomi dikemukakan oleh Prof. DR. J.L Mey JR. Yaitu bahwa ilmu ekonomi adalah ilmu pengetahuan yang mempelajari usaha manusia ke arah kemakmuran. Sedangkan Adam Smith mendefinisikan bahwa ilmu ekonomi adalah ilmu yang mempelajari tingkah laku manusia dalam usahanya untuk mengalokasikan sumbersumber daya yang terbatas guna mencapai tujuan tertentu.

Dari dua definisi tersebut, selanjutnya kita dapat menarik kesimpulan bahwa ilmu ekonomi adalah ilmu pengetahuan sosial yang mempelajari tingkah laku manusia dalam masyarakat secara individu atau secara bersama-sama, dalam usaha untuk memenuhi keburuhan guna mencapai kemakmuran. Kemakmuran adalah keadaan dimana semua kebutuhan kebendaan dapat dipenuhi dengan sebaik-baiknya. Sementara yang dimaksud dengan ahli ekonomi atau ekonom adalah orang menggunakan konsep ekonomi dan data dalam bekerja. Ilmu ekonomi merupakan bagian dari ilmu sosial yang mempelajari masyarakat dari segi pemenuhan kebutuhan. Karena sebagian besar perbuatan manusia ditujukan untuk memenuhi kebutuhan hidup, maka ilmu ekonomi dapat dikatakan memegang peranan penting dalam kehidupan sosial. Ilmu Ekonomi sebagai bagian dari Ilmu
Sosial mendapat julukan sebagai The Queen of the Sosicial Science (ratu ilmuilmu sosial) karena ilmu ekonomi satu dari antara ilmu-ilmu sosial yang menggunakan metode kuantitaif di dalam analisis-analisisnya. Adapun untuk Page | 100 memecahkan persoalan ekonomi, dapat digunakan ekonometri yang merupakan perpaduan ilmu ekonomi dan matematika

\section{Prinsip Ekonomi}

Dinar \& Hasan dalam buku Pengantar Ekonomi teori dan aplikasi (2018:5-6) Dalam ilmu ekonomi kita mengenal suatu kaidah yang dapat dipakai sebagai pedoman umum untuk melakukan tindakan ekonomi. Kaidah itu disebut prinsip ekonomi. Prinsip ekonomi adalah

1. Suatu cara bertindak dengan berusaha mencapai hasil sebesar mungkin (optimal) dibandingkan dengan pengorbanan yang dikeluarkan atau

2. Suatu cara bertindak untuk mencapai hasil tertentu dengan mengeluarkan pengorbanan sekecil mungkin. Istilah lain yang berhubungan dengan prinsip ekonomi adalah efisien. Efisiensi menunjukkan perbandingan yang seoptimal mungkin antara pengorbanan dan hasil. Jadi cara kerja yang efisien menunjukkan bahwa suatu hasil dicapai dengan pengorbanan yang paling sesuai tanpa pemborosan.

\section{Motif Ekonomi}

Dalam buku Pengantar Ekonomi teori dan aplikasi menurut Sukirno, Sadono (2018:6) Motif ekonomi adalah alasan atau hal-hal yang mendorong seseorang melakukan tindakan ekonomi. Motif 
ekonomi bagi seseorang itu berbedabeda, namun motif utama yang mendorong mereka melakukan kegiatan ekonomi adalah keinginan memenuhi kebutuhan hidup untuk mencapai kemakmuran. Adapun motif ekonomi lainnya adalah : 1. Motif memperoleh keuntungan Motif ini merupakan dorongan wajar bagi pengusaha untuk mendapatkan keuntungan yang besar dalam rangka memeperbesar usahanya. 2. Motif memperoleh penghargaan Motif ini merupakan motif agar terpandang dan dihargai oleh masyarakat sekitarnya. Untuk itu ia tampil dengan gaya mewah dan senang memeberi bantuan agar mendapat pujian/penghargaan dari pihak lain. 3. Motif memperoleh kekuasaan ekonomi Motif ini merupakan motif ingin mendapatkan kekuasaan ekonomi, setelah seseorang sukses mengembangkan usahanya dan mendirikan cabangcabang usahanya disetiap kota, ia tetap berusaha mengembangkan usahanya. Kadangkadang motif memperoleh kekuasaan sulit dibedakan dengan motif memperoleh penghargaan 4. Motif sosial / membantu sesama Dalam hal ini kegiatan ekonomi seseorang didorong bukan hanya untuk kepentingan diri sendiri tetapi juga untuk kepentingan berbuat sosial seperti membantu korban bencana alam, memberi sumbangn pada panti asuhan, yayasan tuna netra dll.

\section{Hukum Ekonomi}

Pada buku Pengantar Ekonomi teori dan aplikasi menurut Sukirno, Sadono (2018:7-8) Hukum ekonomi adalah ketentuan-ketentuan yang menerangkan hubungan peristiwa-peristiwa ekonomi. Artinya, bagaimana hubungan suatu peristiwa dengan peristiwa lainnya. Ada 2 (dua) hubungan pertistiwa ekonomi yaitu hubungan sebab akibat dan hubungan saling mempengaruhi. 1. Hubungan Sebab-Akibat (kausal) Hubungan sebabakibat atau hubungan kausal adalah hubungan peristiwa yang satu mengakibatkan peristiwa yang lain. Page|101 Kejadian ini tidak dapat berlaku sebaliknya. Contoh hubungan ini adalah hubungan antara jumlah uang beredar dalam masyarakat dengan kenaikan harga. Apabila jumlah uang beredar bertambah, harga barang-barang akan naik. Hubungan kausal ini tidak dapat berlaku sebaliknya dimana kenaikan harga barang tidak menyebabkan bertambahnya jumlah yang beredar. Bagaimana hubungan antara upah dan harga? kenaikan upah biasanya menyebabkan kenaikan harga. Tapi kenaikan harga tidak menyebabkan kenaikan upah. 2. Hubungan Saling Mempengaruhi (Fungsional) Hubungan saling mempengaruhi adalah hubungan dua peristiwa atau lebih yang saling mempengaruhi. Hubungan saling mempengaruhi disebut juga hubunganfungsional. Contoh hubungan ini adalah hubungan antara harga dengan permintaan barang. Apabila harga suatu barang naik, permintaan atas barang berkurang. Di sini harga mempengaruhi permintaan. Sebaliknya, apabila permintaan bertambah, harga akan naik. Dalam hal ini terjadi hubungan timbal balik dimana harga mempengaruhi permintaan dan sebaliknya permintaan juga mempengaruhi harga. Perlu diketahui bahwa hukum ekonomi itu tidak berlaku mutlak tetapi lebih tepat disebut tendensi atau kecendrungan. Hukum ekonomi berlaku dengan syarat ceteris paribus, yaitu jika hal-hal lain di dalam masyarakat yang diluar objek penelitian tidak berubah. Faktor-faktor ceteris paribus tersebut adalah : a. Pendapatan harus tetap b. Selera (taste) 
orang tetap atau tidak berubah c. Harga barang lain tetap d. Barang substitusi tidak ada e. Pengharapan pada masa depan tetap. Contoh hukum permintaaan yang menerangkan bahwa jika harga naik maka permintaan berkurang dan demikian sebaliknya jika harga turun permintaan bertambah.

\section{Pelaku Ekonomi}

Dalam buku Pengantar Ekonomi teori dan aplikasi menurut Rahardja,Prathama (2018:8) Pada hakikatnya di dalam masyarakat terdapat tiga kelompok pelaku ekonomi, yaitu (1) perorangan yang tergabung dalam rumah tangga keluarga, (2) perusahaan atau rumah tangga produksi, dan (3) pemerintah atau rumah tangga negara. Bagi negara yang mempunyai hubungan internasional masih ada satu kelompok pelaku ekonomi lagi, yaitu (4) masyarakat luar negeri.

\section{PEMBAHASAN}

Pemberdayaan masyarakat strategi guna melakukan pebanguna dalam diri individu masyarakat atau secara keseluruhan wilayahnya dengan memanfaatka kemampuan yang ada dalam diri mereka maupun dari sumber daya lingkungannya. Perilaku masyarakat yang perlu diubah tentunya perilaku yang merugikan masyarakat atau yang menghambat peningkatan kesejahteraan masyarakat. Pemberdayaan selalu mengacu kepada kelompok masyarakat yang berada di lapisan bawah yang karena posisinya itu seringkali menjadi korban dari dinamika pembangunan. Kelompok masyarakat itu menyandang kondisi yang serba lemah dan kekurangan dalam mutu dan taraf hidup, keterampilan, keswadayaan dan sebagainya. Oleh karena itulah, mereka perlu diberdayakan.

Apa yang dikembangkan dari masyarakat yaitu potensi atau kemampuannya dan sikap hidupnya. Kemampuan masyarakat dapat meliputi Page| 102 antara lain kemampuan untuk bertani, berternak, melakukan wirausaha, atau ketrampilan-ketrampilan membuat home industri; dan masih banyak lagi kemampuan dan ketrampilan masyarakat yang dapat dikembangkan. Salah satu upaya yang bisa dilakukan untuk memberdayakan masyarakat adalah melalui lembaga pendidikan non formal. Pendidikan non formal merupakan pendidikan alternatif setelah pendidikan formal. Lifeskill (lembaga kursus) sebagai salah satu bentuk penyelenggaraan pendidikan pada jalur pendidikan non formal mempunyai kaitan yang sangat erat dengan jalur pendidikan formal. Selain memberikan kesempatan bagi peserta didik yang ingin mengembangkan keterampilannya pada jenis pendidikan tertentu yang telah ada di jalur pendidikan formal juga memberikan kesempatan bagi masyarakat yang ingin mengembangkan pendidikan keterampilannya yang tidak dapat ditempuh dan tidak terpenuhi pada jalur pendidikan formal.

Pendidikan non formal merupakan usaha masyarakat dalam mencari jalan keluar terhadap persoalan pendidikan formal yang tidak terjangkau oleh masyarakat. Perhatian pendidikan non formal lebih terpusat pada usahausaha untuk membantu terwujudnya proses pembelajaran di masyarakat. Hal ini sesuai dengan Pasal 55, UU Sisdiknas No.20 tahun 2003 butir pertama yaitu, Masyarakat berhak menyelenggarakan pendidikan berbasis masyarakat pada pendidikan formal dan non formal sesuai 
dengan kekhasan agama, lingkungan sosial, dan budaya untuk kepentingan masyarakat.

Oleh karena itu masyarakat berhak menyelenggarakan pendidikan yang berbasis masyarakat, dengan mengembangkan dan melaksanakan kurikulum dan evaluasi pendidikan, serta manajemen dan pendanaannya sesuai dengan standard nasional pendidikan. Partisipasi masyarakat tersebut kemudian tercipta sebuah lembaga kursus dan pelatihan yang bersumber dari masyarakat untuk masyarakat. Dalam menjalankan tugas sebagai penyelenggara kursus, Lembaga pendidikan non formal atau penyelenggara kursus dan pendidik atau instruktur kursus di berikan kebebasan dalam berorganisasi menjadi mitra pemerintah. Dalam rangka mengembangkan kemampuan dan ketrampilan masyarakat, dapat dilakukan dengan berbagai cara. Misalnya dengan mengadakan pelatihan atau mengikutkan masyarakat pada pelatihan-pelatihan pengembangan kemampuan dan ketrampilan yang dibutuhkan Salah satu upaya yang bisa dilakukan untuk itu adalah melalui lembaga pendidikan non formal, dan salah satu lembaga pendidikan non formal tersebut adalah lembaga kursus Pemerintah melalui Kementerian Pendidikan dan Kebudayaan sebenarnya sudah lama memberikan berbagai bantuan kepada lembaga kursus untuk memberikan kursus gratis khususnya bagi masyarakat yang kurang mampu. Sebagaimana kabupaten lain, di kabupaten Balangan juga terdapat berbagai lembaga kursus yang tersebar di semua kecamatan. Namun berdasarkan studi awal yang dilakukan, peranan lembaga kursus untuk memberdayakan masyarakat khususnya melalui kursus gratis ternyata jauh lebih rendah dibandingkan dengan kabupaten-kabupaten lainnya. Berdasarkan hal tersebut, maka perlu pengkajian secara mendalam berkaitan dengan hal tersebut.

Kemandirian ekonomi Indonesia Page | 103 harus didorong atas dasar penguatan kekuatan ekonomi seluruh rakyat Indonesia dengan tanpa adanya dominasi maupun intervensi pihak asing dan kuasa lokal berdiri paling depan bersama-sama mengejar kesejahteraan rakyat Indonesia di seluruh pelosok Indonesia. Sudah saatnya bangsa Indonesia melakukan kemandirian dalam rangka mewujudkan kehidupan ekonomi yang mapan, adil dan sejahtera. Negara memiliki kemakmuran secara ekonomi adalah negara yang mampu menguasai ekonomi yakni menghasilkan produk-produk unggulan yang berkualitas, teknologi maju dan segala outputnya yang memiliki nilai jual tinggi, hal ini jelas dapat mmacu pertumbuhan ekonomi dan sekaligus meningkatkan kemakmuran.

\section{KESIMPULAN}

Life skill dalam hal ini dalam rangka pemberdayaan masyarakat sebagai proses pengembangan, memandirikan dan memperkuat seluruh lapisan masyarakat. Dalam hal ini diberikan kepada masyarakat yang berada pada kondisi sosial, ekonomi yang tergolong rendah sehingga dapat terperdayakan dengan adanya kegiatan ini. Kegiatan pendidika keterampilan ini selain sebagai pemberdayaan masyarakat juga sebagai langkah pembangunan ekonomi, sebab mempersiapkan masyarakat guna meningkatkan kesejahteraan ekonomi mereka dengan menitik beratkan pada masyarakat yang memiliki atau berada pada kondisi ekonomi rendah. 


\section{Journal of Millennial Community, 3 (2), September 2021}

Ragil Atmaja, Nurlaila, Rahman Arif, Rahmi Atikah

Untuk memajukan potensi daerah perlu bekal pengetahuan teknologi dan inovasi serta kreativitas kearah agropreneurship dan technopreneurship. Untuk itu perubahan cara berpikir dan bertindak sebagai wirausahawan diperlukan. Mencontoh kegiatan pemberdayaan yang berhasil, maka pemberdayaan masyarakat perlu sejalan dengan kegiatan riset.

Pada era global perlu pemberdayaan yang menyeluruh baik aspek mikro dan makro, baik dari dalam diri maupun dari luar yang melibatkan segenap komponen masyarakat. Adanya kompetensi entrepreneur sangat penting. Diperlukan pula pemimpin yang tidak hanya populis, akan tetapi juga mampu sebagai leader maupun manajer dan memiliki kekuatan moral.

Masyarakat sebagai agent of change di masyarakat dalam segala sub kehidupan dilingkungan sosial, termasuk pemberdayaan sesama masyarakat. Setiap anggota masyarakat berhak dan berkewajiban memiliki kesadaran akan sesama anggota masyarakatya untuk memperbaiki lingkungan sosial mereka dari segi ekonomi, pendidikan, dan budaya. Ketika semua individu yang berada dimasyarakat sadar akan hal ini maka sifat gotong royong yang menjadi ciri khas budaya Indonesia dapat menjadi pahlawan dalam pemberantasan kemiskinan dan kesejahteraanpun akan timbul pula dalam semua lapisan masyarakat. Tidak perlu membutuhkan modal materi untuk memberdayakan sesama anggota masyarakat, namun dengan pengetahuan sajapun dapat menjadi senjata yang ampuh seperti memberikan keterampilan, mengembangkan, dan mengorganisir masyarakat hal ini sebagai kegiatan pemberdayaan masyarakat.

\section{DAFTAR RUJUKAN}

Page | 104

Agussalim. (2016). Transcultural Nursing Masyarakat Ekonomi Asean Dan Caring Serta Latihan Critical Thinking. Yogyakarta: Citramaya.

Arief, Budiman. (1995). Teori Pembangunan Dunia Ketiga. Jakarta: Pt Gramedia Pustaka Utama.

Arisah. (2009). Pemberdayaan Masyarakat Dalm Pembangunan Ekonomi Desa. Artikel, Jurnal Wacanavol 12, 2 April 2009.

Avilliani, 2012, Kemandirian Ekonomi, Uin Online-Institute For Development Of Economics And Finance (Indef)

Combs, Philip, H. Ahmad Manzoor. (1985). Memerangi Kemiskinan Di Pedesaan Melalui Pendidikan Nonformal, Jakarta: Rajawali.

Cholisin. (2011) Pengembangan Karakter Dalam Materi Pembelajaran Pkn. Makalah Disampaiakan Pada Kegiatan Mgmp Pkn Smp Kota Yogyakarta.

Dinar, M Dan Hasan, M. (2018). Pengantar Ekonomi: Teori Dan Aplikasi. Makassar: Nur Lina \& Pustaka Taman Ilmu.

Hikmat, R. Harry. (2001). Strategi Pemberdayaan Masyarakat. Bandung: Humaniora Utama Press (Hup)

Faisal Sanapiah. (1981). Dasar Dan Teknik Menyusun Angket. Surabaya: Penerbit Usaha Karya.

Hasan, Muhammad Dan Muhammad Aziz. (2018). Pembangunan Ekonomi Dan 
Pemberdayaan Masyarakat. Makassar: $\mathrm{Cv}$ Nur Lina

Evaluasi, A., Kurikulum, I., \& Kompetensi, B. (N.D.). Evaluasi Implementasi Kurikulum Berbasis Kompetensi Pada Lembaga Kursus Dan Pelatihan ( Lkp ) Competency-Based Curriculum In Course And Training Institutes For Automotive Programs Abstract: The Evaluation Of The Implementation Of CompetencyBased Curriculum In Course, (1), 267-283. Kartasasmita, G. (1996). Pembangunan Untuk Rakyat: Memadukan Pertumbuhan Dan Pemerataan. Jakarta: Cides

Maryunani, Salfitrie Roos And Mirzanti, Isti Raafaldini (2015), "The Development Of Entrepreneurship In Creative Industries With Reference To Bandung As A Creative City" Procedia - Social And Behavioral Sciences Vol 169, Pp. 387-394

Mubyarto. (1991). Pengantar Ekonomi Pertanian. Jakarta: Lpзes.

Nasution, A.H (1975). Teori Statistika. Jakarta: Bhatara Karya.

Nuryasin. Artikel Pemberdayaan Masyarakat Dalam Pembangunan Desa, Sabtu, 12 Februari 2011.

Pamungkas, A. H., Sunarti, V., \& Wahyudi, W. A. (2018). Pkbm Dalam Peningkatan Pertumbuhan Ekonomi Dan Kesejahteraan Hidup Masyarakat Sesuai Target Sdg' S. Spektrum Jurnal Pendidikan Luar Sekolah, Volume 1,(Pkbm, Economic Growth, Welfare, Sdg's), 302-307. Https://Doi.Org/10.5281/Zenodo.1452508

Pengantar Ekonomi Teori Dan Aplikasi, Dinar.M \& Hasan.M, 2018. Cv. Nur Lina.
Penggerak, T. I. M., Dan, P., Keluarga, K., Kaliori, K., Rembang, K., Riana, N. R., ... Hayat, A. (N.D.). ( Studi Tentang Program Pendidikan Dan Keterampilan, 2(5), 851856.

Rachmanda, B. Adityo. Penciptaan Page | 105 Kemandirian Ekonomi Rakyat Dan Umkm Melalui Wawasan Entrepreneur. Fakultas Ekonomi Dan Bisnis, Universitas Brawijaya.

Rahardja. Prathama, Pengantar Teori Ekonomi Mikro, Universitas Indonesia, 1999

Ravinder Kumar, Rajesh K. Singh, Ravi Shankar (2015), "Critical Success Factors For Implementation Of Supply Chain Management In Indian Small And Medium Enterprises And Their Impact On Performance", Iimb Management Review Vol 27,Pp. 92-104.

Solikatun, Supono, Masruroh, \& Zuber. (2014). Kemiskinan Dalam Pembangunan. Jurnal Analisa Sosiologi. Vol 3 No 1

St. Vembriarto. (1981) Pengantar Pengajaran Modul. Yogyakarta: Paramita

Suharto, Edi. (2006). Membangun Masyarakat Memberdayakan Rakyat: Kajian Strategis Pembangunan Kesejahteraan Sosial Dan Pekerjaan Sosial. Bandung: Refika Aditama.

Sukirno, Sadono, Pengantar Teori Ekonomi, Rajawali Pers, 2002.

Sukirno, Sadono, Makro Ekonomi Teori Pengantar , Rajawali Pers, 1994

Sumaryo. (1991). Implementasi Rural Apparsial (Pra) Dalam Pemberdayaan Masyarakat. Disampaikan Dalam Pelatihan Pengorganisasian Masyarakat Dalam Rangka Peningkatan Mutu Pengabdian Pada Masyarakat, Di Iain 
Raden Intan Bandar Lmpung, 26 November 2005.

Sumodiningrat. (1996). Pembangunan Daerah Dan Pemberdayaan Masyarakat. Jakarta: Bina Rena Pariwira.

Suradi. 2012. Faktor-Faktor Yang Mempengaruhi Minat Beli Konsumen Terhadap Produk Tepung Sagu. Http://P3m.Polbeng.Ac.Id/Dataq/File_C ontent/File/Abstrak_Ta_Mahasis Wa/Adm/Jurnal\%2oadm\%2osuradi.Pdf

Syawie, M. Dkk. (2007). Kemiskinan Dan Kesenjangan Sosial. Jurnal Kemiskinan Dan Kesenjangan Sosial. Vol 163 No 3, Hal 213-218.

Tapian, Dkk. (2011). Characterization Of Quinoa Protein-Chitosan Blend Edible Films. Food Hydrocolloids. Vol 25, Hal 879-886.

Wilonoyudho, Saratri. (2009). Kesenjangan Dalam Pembangunan Kewilayahan. Surakarta: Jurnal Forum Geografi Universitas Muhammadiyah Surakarta. Vol 23.

Wrihatnolo, Rany. R Dan Riant Nugroho D. (2007). Manajemen Pemberdayaan: Sebuah Pengantar Dan Paduan Untuk Pemberdayaan Masyarakat. Jakarta: Gramedia 